\title{
economies
}

ISSN 2227-7099

www.mdpi.com/journal/economies

Article

\section{Effects of Primary, Secondary and Tertiary Education on Conflict Intensity in Africa}

\author{
Julius A. Agbor \\ Department of Economics, Stellenbosch University, Cape Town, 7602, South Africa; \\ E-Mail: jagbor1970@gmail.com; Tel.: +1-240-506-2353 \\ Academic Editor: Nishith Prakash
}

Received: 2 August 2015 / Accepted: 30 September 2015 / Published: 9 October 2015

\begin{abstract}
This study investigates the impact of different schooling dimensions (primary, secondary and tertiary) on the intensity of intra-state conflicts in 25 African states during the period 1989-2008. It uses fixed-effects and Generalized Methods of Moments (GMM) estimators in an annualized panel data framework. Parameter estimates suggest the following (1) primary schooling broadly mitigates conflicts in Africa. However, in environments with high natural resource rents, it could ignite conflicts; (2) there is evidence, although not overwhelming, that secondary schooling potentially drives conflicts in Africa. There is also evidence that urbanization potentially drives conflicts in Africa. However, although secondary schooling and urbanization potentially drives conflicts, in environments where secondary schooling (urbanization) is high, urbanization (secondary schooling) mitigates conflicts; (3) there is no evidence of a strong direct positive impact of tertiary education on conflicts and conditioning on tertiary schooling, income inequality potentially drives conflicts in African states. However, in contexts where income inequality (tertiary schooling) is high, tertiary schooling (inequality) mitigates conflict. Two important policy implications follow from this study. First, in contexts where income inequality is high (for instance, in South Africa), governments should strive to foster tertiary education in order to reduce conflict. Second, where urbanization rates are high, they should foster both secondary and tertiary education. This study contributes to existing knowledge by clearly demonstrating the utility of distinguishing between different educational dimensions and the contexts wherein they matter for conflict mitigation in Africa.
\end{abstract}

Keywords: school education; conflict; economic development; Africa

JEL classifications: $\mathrm{O} 43$; O15; O11 


\section{Introduction}

The theoretical development literature has long emphasized the two-faces of education in conflict. On the one hand, education is seen as a powerful tool for achieving peace by reducing the likelihood of violent societal conflict, enhancing social cohesion, ${ }^{1}$ reducing inequalities, improving mutual understanding amongst people and by enhancing the respect for diversity. On the other hand, several other theories have upheld the destabilizing power of education by raising political aspirations, enhancing the fighting technology, increasing the number of belligerents, promoting socio-economic inequalities, and by nurturing sectarian or extremist views. Despite its imminent appeal to development theorists, few quantitative studies have researched the education-conflict nexus.

In a most comprehensive survey of the existing empirical literature, Ostby and Urdal (2010) [2] find that only a few quantitative conflict studies, notably, Barakat and Urdal (2009) [3], Krueger and Malečkova (2003) [4], and Thyne (2006) [5]; have had education as their primary focus. Of the thirty studies reviewed, Ostby and Urdal (2010) [2] find that only seven of them (Barakat and Urdal (2009) [3], Berrebi (2007) [6], Fair (2008) [7], Krueger and Malečkova (2003) [4], Oyefusi (2008) [8], Shayo (2007) [9], and Thyne (2006) [5]) have the word "education" as a part of the title and among these the vast majority are micro-level studies. Interestingly, most of the macro-and meso-level studies have focused on the conflict potential of various levels of education, as Ostby and Urdal (2010) [2] suggest. Further, there seem to be a growing consensus in the empirical literature that countries with higher average levels of education do indeed have a lower risk of experiencing armed conflict.

Yet, the empirical literature remains largely unclear on two important issues namely, which educational dimension or level (primary, secondary or tertiary) matters the most from a policy perspective, and which other policies should be associated with educational policies (in other words, the likely transmission mechanisms) in order to bring about a significant reduction in civil conflict. These are crucial concerns, particularly for poor developing countries that have to grapple with both insufficient national budgetary capacities and a whole lot of other developmental problems. Thus, research that provides some indication of the educational dimension with the highest returns in terms of conflict mitigation is of crucial importance to developing countries.

Further, an investigation into the impact of different educational levels on conflict is mandated by the findings of prior empirical studies which seem to suggest that different educational levels have different impacts on conflict. For instance, while there is broad empirical evidence in support of the premise that secondary enrolment - the dimension most researched in the education-conflict empirical literaturepacifies conflict, the few studies which have examined the tertiary dimension of education (notably, Thyne (2006) [5], Urdal (2008) [10], Bussmann (2007) [11] and Besançon (2005) [12]) do not suggest a clear relationship between tertiary education and conflict risk ${ }^{2}$. Ostby and Urdal (2010) [2] have recently concluded that "it is still unclear whether (and if) tertiary education is related to conflict risk".

\footnotetext{
${ }^{1}$ The World Bank has unequivocally stressed its faith in the key significance of education and lifelong learning in reinforcing social cohesion: "by improving people's ability to function as members of their communities, education and training increase social cohesion, reduce crime and improve income distribution", World Bank (2002) [1].

${ }^{2}$ While Thyne (2006) [5] finds no significant effect of higher education on conflict, Besançon (2005) [12] finds that higher tertiary education levels increase the risk of ethnic wars and genocides, whereas they lower the risk of revolutions. Bussmann (2007) [11] on his part finds that tertiary education has an overall pacifying effect. The underlying message
} 
Besides this inconclusive evidence about the impact of different educational dimensions on conflict, our knowledge of the likely transmission mechanisms between increasing educational levels and conflict reduction is also very limited. Prior evidence reveals that the context of economic underdevelopment, youth bulge ${ }^{3}$, natural resources dependency ${ }^{4}$, and deficient democratic institutions ${ }^{5}$ might have preponderant effect on the education-conflict nexus. By aiming to explore in greater detail these contextual factors or transmission mechanisms between education levels and conflict, the present study fills an important void in the education-conflict literature.

The focus of this study is on African states, given their high propensity of civil conflicts and the high correlation between observed periods of socio-political conflicts and episodes of negative economic growth. ${ }^{6}$ This study builds on an earlier contribution by Agbor (2011) [16], which finds evidence in support of the claim that schooling education, as measured by the average schooling years in the population aged 15 and above, reduces the likelihood of societal conflicts in Africa. By focusing on the intensity (proxied here by the per capita number of intra-state battle-related deaths), rather than the likelihood of societal conflict, the present study not only addresses a relatively new conflict dimension but also one with potentially important policy implications given the huge cost of conflict casualties to society in terms of lost human lives, lost potential and output.

The study utilizes the Uppsala/PRIO dataset of armed intra-state conflicts (Gleditsch et al (2002) [17]: probably the most authoritative conflict dataset to-date) for 25 African countries during 1989-2008. The intensity of intra-state conflict for a given country in each year is proxied by the per capita number of intra-state battle-related deaths for that year. Typically, the Uppsala conflict database defines an active episode of intra-state conflict as one where there is a clearly stated goal of incompatibility between belligerents over a territory or government involving the use of armed force and which results in at least 25 battle-related deaths. Because the 25-deaths minimum threshold for conflict does not conveniently capture various conflict intensities, and consistent with the tradition in the literature, I focus directly on the per capita number of battle-related deaths in each year.

Parameter estimates using fixed effects and GMM estimators suggest the following (1) primary schooling broadly mitigates conflicts in Africa. However, in environments with high natural resource rents, it could ignite conflicts; (2) there is evidence, although not overwhelming, that secondary schooling drives conflicts in Africa. There is also evidence that urbanization drives conflicts in Africa. However, although secondary schooling and urbanization potentially drives conflicts, in environments where secondary schooling (urbanization) is high, urbanization (secondary schooling) mitigates conflicts; (3) there is no evidence of a strong direct positive impact of tertiary education on conflicts and

behind all these studies is that education does not necessarily have the same pacifying effect on all kinds of conflict.

${ }^{3}$ For example, Barakat and Urdal (2009) [3] find that low rates of male secondary education are more likely to cause conflict in societies with large young male population bulges, particularly in poor countries, and particularly in Sub-Saharan Africa.

${ }^{4}$ Investigating the context of youth bulges in natural resource dependent economies, Barakat and Urdal (2009) [3] find some evidence indicating that the presence of large youth cohorts with low education significantly increases the risk of conflict in countries with high dependence on natural resource.

${ }^{5}$ Hegre (2003) [13] find that increasing literacy rates decrease the risk of armed conflict in countries with functional democracies, but the relation is not verified in the context of non-functional democracies.

${ }^{6}$ See Aryeetey and Fosu (2002) [14]. Blomberg et al. (2006) [15] also provide evidence of conflict lowering growth and lower growth raising the likelihood of conflict. 
conditioning on tertiary schooling, income inequality drives conflicts in African states. However, in contexts where income inequality (tertiary schooling) is high, tertiary schooling (inequality) mitigates conflict. Two important policy implications follow from this study. First, in contexts where income inequality is high (for instance, in South Africa), governments should strive to foster tertiary education in order to reduce conflict. Second, where urbanization rates are high, they should foster both secondary and tertiary education. This study contributes to existing knowledge by clearly demonstrating the utility of distinguishing between different educational dimensions and the contexts wherein they matter for conflict mitigation in Africa.

The rest of the paper is organized as follows: section two is the theoretical framework linking education to conflict while section three outlines the methodology of the study. Section four discusses the results and some robustness checks while section five concludes.

\section{Why Education Matters for Conflict}

Two main opposing schools of thought on the association between education and societal conflict can be identified in the literature, namely: the social stability and social destabilization schools. On the one hand, the social stability school, whose main proponent is Acemoglu and Robinson (2001) [18], holds that resource transfers or redistribution from so-called elites to the disadvantaged represent an attempt at purchasing social stability which is a necessary condition for sustainable economic growth. According to this view, educating the poor is a way of raising their opportunity cost of conflict, suggesting that human capital transfers and conflict are inversely related. For instance, Collier and Hoeffler (2004) [19] have suggested that raising the level of educational attainment, at particularly the secondary level, helps pacify society by raising the opportunity cost of young people joining rebel militia.

This view has been largely endorsed by development institutions, notably the World Bank. For instance, a World Bank report by Akoki et al. (2002) [20] suggest that government investment in education has a direct and lasting positive impact on people's lives, which might directly reduce the level of grievances in society. To the extent that grievances motivate some forms of civil conflict, education might pacify societies. However, as some researchers have argued, government investment in education should not just be an across the board spending which tends to disproportionately favor higher education (and thus, the wealthy segment of society) at the expense of the poor vulnerable segments of the population. Such across the board spending might exacerbate socio-economic inequalities, which might in turn spur grievances and ignite conflicts rather than reduce them. Consistent with this reasoning, Thyne (2006) [5] makes the case for governments, particularly those in poor societies, to focus on primary school enrolment, rather than tertiary enrolment, as a grievance mitigation strategy.

One variant of the social stability hypothesis argues that education promotes social cohesion by helping people to work together peacefully on the one hand, and on the other hand, by encouraging political participation and institutional pathways for resolving conflicts instead of the use of violence. Following this line of reasoning, proponents have advocated for a greater emphasis on secondary and tertiary enrolment, at the expense of primary enrolment, see notably, Alesina and Perotti (1996) [21], Hegre (2003) [13], Hibbs (1973) [22] and Huntington (1968) [23].

Another variant suggests that education lowers conflicts by changing time preferences of individuals from the short run to the long run, implying that less educated people have a higher time preference for 
current, as opposed to future consumption and consequently, are more likely to engage in criminality and violence as a way of satisfying their immediate needs. ${ }^{7}$ The obvious implication of this is that more emphasis should be placed on higher levels of school enrolment at the expense of primary enrolment. Yet another variant, suggests that class conflict would be eliminated as a result of the transfer of human capital from the elite to the poor, because of the complementarity between physical and human capital. ${ }^{8}$

On the other hand, the social destabilization school of thought argues that education increases the likelihood of societal conflicts. Again, the approaches here are varied. In one tradition, it is the ability of education to raise the political aspirations of its recipients that contributes in lowering, not raising, the opportunity cost of conflicts, as postulated by the social stability proponents. ${ }^{9}$ In the tradition of Hirshleifer (1995) [33] and Bates et al. (2007) [34], education potentially raises the likelihood of conflicts through two ways: by enhancing the fighting technology of belligerent parties and by increasing the number of contestants in a conflict. ${ }^{10}$

In another tradition, education potentially compromises social peace through rising socio-economic inequalities and individualism. ${ }^{11}$ Yet another tradition holds that by exacerbating ethnic diversity, education ignites ethno-political conflicts, ${ }^{12}$ while another tradition sees the mis-match between education and jobs as the primary mechanism through which education compromises social peace. ${ }^{13}$ Lastly, some authors blame the inherently violent nature of certain type of educational curricula for promoting intolerance and extremism. ${ }^{14} \mathrm{~A}$ rather extreme view of the link between education and conflict holds that conflicts are an off-shoot of every modernization process in society (see notably, Huntington (1968) [23] ${ }^{15}$ and Senghaas (1998) [46] ${ }^{16}$ ). According to this view, societies exposed to modernization processes are ultimately in a permanent state of conflict with themselves.

In support of the social destabilization hypothesis of education, a number of social scientist, notably, Klaus (2004) [47], Bush and Saltarelli (2000) [37], Davies (2004) [35] and Aguilar and Richmond (1998) [48], have questioned the civilizing power of education. In a highly controversial paper, Bush and Saltarelli (2000) [37] argue that "in many conflicts around the world, education is part of the

\footnotetext{
${ }^{7}$ Proponents of this view include Becker and Mulligan (1997) [24], Becker (1996) [25], and Arrow (1997) [26].

${ }^{8}$ See Galor and Moav (2006) [27].

${ }^{9}$ See notably, Fedderke and Kularatne (2008) [28], Bourguignon and Verdier (2005) [29], and Huntington (1968) [23]. Apter (1955) [30], Foster (1965) [31], and McWilliam and Kwamena-Poh (1978) [32] also provide evidence in support of this viewpoint.

${ }^{10}$ In Hirshleifer's model, more knowledge acquired from schooling means a better technology of fighting and an increasing number of unemployed graduates implies an increased number of potential belligerents.

${ }^{11}$ See notably, Davies (2004) [35] and Vriens (2003) [36].

12 See notably, Bush and Saltarelli (2000) [37] and Smith and Vaux (2003) [38].

${ }^{13}$ See notably, Huntington (1968) [23], Urdal (2006) [39], Choucri (1974) [40], Goldstone (2001) [41], Lia (2005) [42], Boyden and Ryder (1996) [43], Apter (1955) [30], and Lange (2003) [44].

${ }^{14}$ See notably, Davies (2004) [35], and Sommers (2001) [45].

${ }^{15}$ Huntington (1968) [23], for instance, argues that: "Social and economic change. ... extends political consciousness, multiply political demands, broaden political participation... These changes undermine traditional sources of political authority and traditional political institutions... The result are political instability and disorder...".

${ }^{16}$ Senghaas (1998) [46], also argues that education is capable of unleashing and multiplying conflicts: "Development (...) is inevitably conflictual, destabilizing and subversive because it challenges the established power structures that prevent individuals and groups from reaching their full potential".
} 
problem, not the solution". Aguilar and Richmond (1998) [48] question the education received by the protagonists and the main perpetrators of the Rwandan genocide in 1994: "The role of well-educated persons in the conception, planning and execution of the genocide requires explanation any attempt at explanation must consider how it was possible that their education did not render genocide unthinkable. The active involvement of children and young people in carrying out acts of violence, sometimes against their teachers and fellow pupils, raises further questions about the kind of education they had received."

Davies (2004) [35] has also alluded to the involvement of well-educated persons in some of the worst atrocities of modern times, referring to the generally outstanding education biographies of the assassins of the September 11th terrorist attacks and the key personalities within Al Qaeda movement.

While an abundant volume of theoretical literature does exists attesting to either the stabilizing or destabilizing role of education in conflict generally, the evidence about the impact of different educational dimensions on conflict remains inconclusive. In addition, our knowledge of the likely transmission mechanisms between educational levels and conflict is also very limited. The present study contributes to existing knowledge by examining the differential impacts of educational levels on conflict intensity. Further, by aiming to explore the contextual factors or transmission mechanisms between educational levels and conflict, the present study fills an important void in the education-conflict literature.

\section{Methodology}

This section describes the empirical model, the estimator, the estimation strategy and also presents the variables and datasets used in the study.

\subsection{Empirical Model}

This paper assesses the impact of different dimensions of education-primary, secondary and tertiary — on the intensity of intra-state conflicts in Africa. It does this by specifying the following linear regression model:

$$
\text { CIVOT }_{i t}=\lambda L A G C I V O T_{i t}+\alpha E D U C_{i t}+\beta X_{i t}+\gamma I N T E R A C T_{i t}+\mu_{i t}+\varepsilon_{i t}
$$

Where:

CIVOT $_{i t}$ is a numerical variable measuring the intensity of conflicts and is proxied by the per capita number of intra-state battle-related deaths ${ }^{17}$ for each country in each particular year during 1989-2008.

LAGCIVOT $_{i t}$ is the lagged dependent variable to control for conflict persistence over time.

$E D U C_{i t}$ is the education level, which in this case, is either gross primary, gross secondary or gross tertiary school enrolment.

\footnotetext{
${ }^{17}$ The UCDP database defines battle-related deaths as conflict behavior between warring parties in the conflict dyad, which is directly related to some known incompatibility, i.e., carried out with the purpose of realizing the goal of the incompatibility and results in deaths. This includes traditional battlefield fighting, guerrilla activities (e.g., hit-and-run attacks/ambushes) and all kinds of bombardments of military bases, cities and villages. Although urban warfare (bombs, explosions, and assassinations) does not resemble what happens on a battlefield, deaths resulting from such are considered as battle-related. In same wise, all fatalities - military as well as civilian - incurred from attacks on military forces or representatives for the parties are counted as battle-related deaths.
} 
$X_{i t}$ is the matrix of country-year control variables that are standard in the conflict literature, notably, macroeconomic conditions, natural resource dependence, the extent of political participation, a measure of income inequality, an indicator of labor market conditions, urbanization, and the proportion of young men aged between 15 and 24 in the total population (youth bulge).

INTERACT $T_{i t}$ is the matrix of interaction terms between the relevant education dimension and some of the controls considered as likely transmission channels.

$\alpha$ is a vector of slope coefficients that are common to all countries.

$\mu_{i t}$ is a vector of individual country effects reflecting unobservable country heterogeneity and,

$\varepsilon_{i t}$ is a vector of error terms.

\subsection{Choice of Estimator}

This study utilizes the Uppsala Conflict Database of armed intra-state conflicts during 1989-2008 (drawn from the Uppsala Conflict Data Program Database Categorical Variables 1989-2008), for 25 African countries. The intensity of intra-state conflict for a given country in each year is proxied by the per capita number of intra-state battle-related deaths for that year. Typically, the Uppsala conflict database defines an active episode of intra-state conflict as one where there is a clearly stated goal of incompatibility between belligerents over a territory or government involving the use of armed force and which results in at least 25 battle-related deaths. The UCDP categorizes conflict intensity in only two categories: high intensity or war (when there are at least 1000 battle-related deaths) and minor intensity (when there are at least 25 but fewer than a 1000 battle-related deaths). However, because the 25-deaths minimum threshold for defining an active conflict does not conveniently capture cross-country conflict intensities over time, I focus directly on the per capita number of battle-related deaths in each country in each year. Noteworthy that the episodes of intra-state conflicts considered in this study ignore whether or not there was a foreign involvement in the domestic conflict. ${ }^{18}$

Accordingly, the dependent variable in the empirical model specified in equation (1) above (CIVTOT) is continuous. The ideal estimator for estimating these types of linear regression models is the panel fixed-effects model since it accommodates for country-specific unobserved effects. However, a number of econometric problems are associated with the estimation of equation (1) above. These relate mainly to possible endogeneity, simultaneity, heteroscedasticity of residuals, and the assumption of a uniform slope coefficient for the education variables.

First, regarding the problem of conflict persistence over time, I include the lagged dependent variable in all model specifications, though admittedly, lagged dependent variables are not suitable for fixed effects models. However, this problem is overcome with the use of clustered errors with a lagged dependent variable.

Second, to avoid reverse causality running from the dependent variable to the explanatory variables, and following the evidence suggested by Arellano and Carrasco (2003) [49], I use instead the first lagged values of all potentially endogenous explanatory variables. Already, the fixed-effects model handles any

\footnotetext{
${ }^{18}$ Due to data unavailability, these episodes ignore any foreign involvement in the domestic conflict. Although, the specific aspect of the conflict investigated that is, its intensity, is likely to increase with foreign involvement, the influence of foreign involvement is likely to under-estimate, rather than overestimate the impact of education on conflict intensity, assuming that in highly intense conflict situations educational outcomes are negatively affected.
} 
likely problems of endogeneity arising from the fact that either some of the explanatory variables might be correlated with the un-observed country effects or some omitted variables might concurrently affect the dependent variable as well as some of the explanatory variables.

Third, to capture the possibility of conflict in one country spilling over to a neighboring country, I regroup the countries in my sample in four cluster groups according to their respective regions (North Africa, Central Africa, West Africa and East Africa) and use standard errors clustered by groups within the different regional blocks.

Fourth, because the impact of education on conflict might also depend on the conflict intensity level (impacting differently in low and high conflict episodes), the impact of education on conflict might also vary from one conflict episode to another or from one year to another. I address this problem in two ways: first by including in all models specifications a dummy for high conflict intensity episodes ${ }^{19}$ (HIGHCON) and second, by including year dummies to control for unobserved time-specific effects. Finally, to deal with heteroscedasticity of residuals, I use robust standard errors.

As check for robustness of my main results, I run a one-step GMM estimation on the empirical model (1) above, including year dummies and controls for high conflict intensity.

\subsection{Estimation Strategy}

For each of the education dimensions (primary, secondary and tertiary), I run a set of fixed effects models aimed at investigating (1) the likely impact of education on conflict intensity and (2) the likely channels through which education affects conflict intensity. Regarding the likely impact of education on conflict intensity, I run a baseline model in the first place, where the education variable alone explains conflict intensity. I then extend this baseline model to include the full set of conditioning variables. To investigate the likely channels through which education affects conflict intensity, I introduce interaction terms of the education variables and those variables found significant. Finally, as robustness check, I repeat the whole exercise, this time using a one-step GMM estimation technique.

\subsection{Variables and Data}

The analysis on the empirical model specified in equation (1) above is performed using a core dataset of twenty five (25) African countries during 1989-2008. The principal explanatory variable is gross school enrolments which take three different dimensions: primary, secondary and tertiary enrolment rates. Unless otherwise mentioned, data for most variables used in the study are obtained from the African Development Indicators of the World Bank. Informed by the conflict literature, the study uses annualized data for a set of six conditioning variables, namely:

- Inflation (INFL) to capture macroeconomic conditions that might affect conflict. One of the frequent causes of urban uprising in Africa, as Bates (1981) [50] argues, is rising inflation. During inflationary situations, the opportunity cost of conflict is lower. Hence, a positive sign is expected on the inflation variable.

- Youth bulge (YBULGE): is used to control for the propensity of conflict arising from a significant presence of "rascals", that is, young men between the ages of 15 and 24 , in the total population. The data

\footnotetext{
${ }^{19}$ HIGHCON takes on the value 1 for CIVTOT $>2.95$ (which is the mean value for CIVTOT) and 0 otherwise.
} 
is obtained from Collier et al. (2006) [51] whose empirical results suggest a positive significant relationship between youth bulge and the propensity of conflict. This is explained by the fact that a great availability of potential recruits as rebel soldiers makes it easier and cheaper to start a rebellion.

- Urbanization (URBAN): to control for the effects of rising urbanization on the propensity of conflict. Bates (1981) [50] has argued that rising urbanization is a chief source of conflict in Africa, as it produces a pool of unemployed people who easily become rebel recruits. ${ }^{20}$ However, Collier and Hoeffler (2004) [19] find a positive link between urbanization and political stability, working through enhanced productivity and growth. Thus, URBAN is utilized in the models as a proxy for labor market conditions but as expected, the sign on this variable is imprecise.

- Income inequality (GINI): to capture the effects of income inequality on the likelihood of conflict escalating. The political economy literature recognizes the existence of vertical inequalities, notably, high and sustained differences in income and wealth between the rich and the poor, as a potential source of societal conflict, whence the need for redistributive policies as a way of purchasing social peace. The expectation thus, is that a higher gini coefficient increases the likelihood of conflicts.

- Institutionalized Democracy (DEMOC): This variable captures the extent to which non-elites are able to access institutional structures of political expression. Several authors, notably, Duffield (2001) [54], have postulated that the prevalence of conflict today is related more to issues of political transformation and globalization than to persistent poverty. The lack of political space might raise frustrations amongst segments of the population leading to violent socio-political unrest, as observed recently in the Arab world. Murshed (2002) [55] and Elbadawi and Sambanis (2000) [56] have also echoed the importance of a functioning social contract, as greed and grievances are managed and conflict is contained in countries with properly operating institutions. The expectation thus, is for a negative sign on the variable.

- Total natural resource rents as a percentage of GDP (NRES): this is the sum of oil rents, natural gas rents, coal rents (hard and soft), mineral rents, and forest rents to capture the extent to which low education levels contribute in igniting conflicts in natural resource dependent economies. As Ross (2004) [57] suggests, oil rents increase the likelihood of conflict, particularly separatist conflict, while "lootable" commodities like gemstones and drugs tend to lengthen existing conflicts, although they do not make conflict more likely to begin. Yet, as Ross (2004) [57] further shows, the association between primary commodities' rents - a broad category that includes both oil and agricultural goods - and the onset of civil war is not robust. Therefore the expected sign on this variable is imprecise.

Admittedly, some key drivers of conflict like ethno-linguistic fractionalization ${ }^{21}$ have been omitted from our set of conditioning variables mainly because the fixed effects model would not provide parameter estimates for time-invariant regressors. This should however not constitute a significant setback as the fixed effects makes allowance for omitted country-specific characteristics. Table 1 below

${ }^{20}$ Auvinen (1997) [52] and Annett (2001) [53] also find a negative relationship between urbanization and political stability. Obviously, a direct measure of unemployment would have been more desirable but the paucity of long time series data on African countries precludes this option.

${ }^{21}$ See the evidence notably by Fearon and Laitin (2003) [58], and Bleaney and Dimico (2002) [59]. Elbadawi and Sambanis (2000) [56] however hold the opposite view that the relatively higher incidence of war in Africa is not due to the ethnolinguistic fragmentation of its countries, but rather to high levels of poverty, failed political institutions and economic dependence on natural resources. 
summarizes the variables included in the study, Table 2 provides a list of countries included in the sample while Table 3 provides summary descriptive statistics. Table 4 presents the matrix of correlation coefficients for the full sample of countries.

Table 1. Variable list and sources.

\begin{tabular}{cc}
\hline Variable & Source \\
\hline Gross primary Enrolment (PRI) & ADI/World Bank \\
Intra-state Conflict Intensity (CIVITOT) & Author's construction using \\
Gross Secondary Enrolment (SEC) & Uppsala Conflict Dataset \\
Gross Tertiary Enrolment (TER) & ADI/World Bank \\
Pouth Bulge, Proportion of young men aged 15-24 in total & ADI/World Bank \\
population (YBULGE) & \\
Institutionalized Democracy (DEMOC) (2006) [51] \\
Urbanization (URBAN) \\
Inflation (INFL) & ADI/World Bank \\
Total Natural Resource Rents as \% of GDP (NRES) & ADI/World Bank \\
Income Inequality (GINI) & Thi/World Bank \\
\end{tabular}

Table 2. List of the 25 African Countries included in the Sample

\begin{tabular}{cc}
\hline Algeria & Central Africa Republic \\
Angola & Egypt \\
Burundi & Guinea \\
Chad & Guinea Bissau \\
Congo DRC & Ivory Coast \\
Ethiopia & Mali \\
Liberia & Morocco \\
Mozambique & Niger \\
Rwanda & Nigeria \\
Senegal & Togo \\
Sierra Leone & Congo Republic \\
Sudan & Djibouti \\
Uganda & \\
\hline
\end{tabular}


Table 3. Summary Descriptive Statistics.

\begin{tabular}{cccccc}
\hline Variable & Obs. & Mean & Std. Dev. & Min & Max \\
\hline Conflict Intensity & 207 & 2.947 & 1.795 & -1.172 & 8.155 \\
Primary Enrolment & 434 & 4.263 & 0.405 & 3.127 & 5.154 \\
Secondary Enrolment & 380 & 2.947 & 0.662 & 1.496 & 4.421 \\
Tertiary Enrolment & 336 & 0.85 & 1.131 & -2.346 & 3.56 \\
Inflation & 378 & 2.161 & 1.702 & -3.206 & 10.076 \\
Urbanization & 494 & 1.3 & 0.481 & -1.605 & 10.076 \\
Institutionalized Democracy & 242 & 1.017 & 0.785 & 0 & 2.079 \\
Income Inequality & 480 & 3.745 & 0.177 & 3.393 & 4.141 \\
Youth Bulge & 499 & 2.978 & 0.066 & 2.856 & 3.314 \\
Natural Resource Rents & 499 & 1.899 & 1.467 & -7.271 & 5.388 \\
\hline
\end{tabular}

NB: All variables are logged to base ten. In addition, all variables excluding Conflict Intensity and Inequality are lagged by one period (a year). Note also that the conflict intensity figures are in per million of the population of each country.

Table 4. Matrix of correlation coefficients.

\begin{tabular}{|c|c|c|c|c|c|c|c|c|c|c|}
\hline & CIVTOT & PRI & SEC & TER & INFL & URBAN & DEMOC & GINI & NRES & YBULGE \\
\hline CIVTOT & 1.00 & & & & & & & & & \\
\hline PRI & -0.04 & 1.00 & & & & & & & & \\
\hline SEC & 0.01 & $0.45 * * *$ & 1.00 & & & & & & & \\
\hline TER & -0.04 & $0.37 * * *$ & $0.84 * * *$ & 1.00 & & & & & & \\
\hline INFL & -0.02 & -0.02 & -0.07 & -0.03 & 1.00 & & & & & \\
\hline URBAN & -0.03 & 0.01 & $-0.33 * * *$ & $-0.21 * * *$ & 0.02 & 1.00 & & & & \\
\hline DEMOC & -0.06 & $0.10^{* *}$ & -0.07 & 0.02 & $-0.21 * * *$ & 0.01 & 1.00 & & & \\
\hline GINI & 0.03 & 0.02 & $-0.34 * * *$ & $-0.33 * * *$ & 0.06 & 0.04 & $-0.09 * *$ & 1.00 & & \\
\hline NRES & $0.10^{* *}$ & $0.30^{* * *}$ & $0.13 * *$ & $0.11^{* *}$ & 0.03 & -0.03 & -0.06 & $0.26^{* * *}$ & 1.00 & \\
\hline YBULGE & -0.02 & $0.35^{* * *}$ & $0.36^{* * *}$ & $0.33^{* * *}$ & -0.07 & 0.04 & 0.02 & $-0.16^{* * *}$ & -0.04 & 1.00 \\
\hline
\end{tabular}

\subsection{Inferences from the Empirical Data}

Table 4 presents pair-wise correlations of all the variables included in the model. It can be observed a strong correlation between all the education dimensions but virtually no correlation between either dimension of education and conflict intensity. This suggests that the relationship between schooling enrolments and conflict intensity, if any, might be indirect, whence the intuition to use interaction terms in the model specifications. Table 4 also informs that primary enrolment rates are strongly correlated with institutionalized democracy, natural resource rents and youth bulge, while secondary enrolment rates are strongly correlated with urbanization, natural resource rents and youth bulge. Tertiary enrolment rates are strongly correlated with urbanization, natural resource rents, inequality and youth bulge. The key insight from Table 4 is that, the education-conflict nexus might well be mediated by different transmission mechanisms. 


\section{Discussion of the Results}

\subsection{Analysis of Fixed Effects Estimation Results}

Tables 5-7 present fixed effects estimates on several different specifications on Equation (1) above considering as the main explanatory variable; the primary, secondary and tertiary dimensions of education respectively.

In Table 5 where primary schooling is the principal explanatory variable, the results in Model 1 show that primary schooling has a mitigating effect on intra-state conflict intensity in Africa, although the impact is statistically insignificant. Interestingly, after including our full set of conditioning variables, primary schooling is found to raise the intensity of conflict though the effect is only statistically significant at the 10\% level (Model 2). Model 2 results further tell us that conditioning on primary schooling; inequality and youth bulge are significant drivers of conflict. The positive statistically significant sign on the high conflict dummy (HIGHCON) suggests that primary schooling might impact on conflict differently in high and low conflict environments whence the need to interact primary schooling with the HIGHCON dummy. The next step thus involves interacting primary schooling with HIGHCON (Model 3), inequality (Model 4) and youth bulge (Model 5) controlling for the full set of conditioning variables. Model 3 results suggest that, although primary schooling generally raises the conflict intensity, in environments where the conflict intensity is already high, primary schooling helps reduce this. This mitigating influence of primary schooling is however, not statistically significant. Models 4 and 5 which respectively test for the inequality and youth bulge transmission channels, fail to validate the importance of these two channels of transmission. Instead, we observe a change in the sign of the primary schooling coefficient to negative suggesting that the overall impact of primary schooling is to reduce not ignite conflicts. 
Table 5. Fixed effects results on primary schooling.

\begin{tabular}{|c|c|c|c|c|c|c|}
\hline \multicolumn{7}{|c|}{ Dependent Variable: Conflict Intensity } \\
\hline & Model 1 & Model 2 & Model 3 & Model 4 & Model 5 & Model 6 \\
\hline Conflict Intensity (Lagged) & $\begin{array}{c}0.11 \\
{[0.113]}\end{array}$ & $\begin{array}{c}-0.15 \\
{[0.244]}\end{array}$ & $\begin{array}{c}-0.16 \\
{[0.241]}\end{array}$ & $\begin{array}{c}-0.15 \\
{[0.254]}\end{array}$ & $\begin{array}{c}-0.25 \\
{[0.153]}\end{array}$ & $\begin{array}{c}-0.25 \\
{[0.166]}\end{array}$ \\
\hline Primary Enrolment & $\begin{array}{c}-0.23 \\
{[0.503]}\end{array}$ & $\begin{array}{c}3.30 * \\
{[1.251]}\end{array}$ & $\begin{array}{c}3.82 * * \\
{[1.162]} \\
\end{array}$ & $\begin{array}{c}-0.33 \\
{[27.828]} \\
\end{array}$ & $\begin{array}{c}-322.6 \\
{[214.032]}\end{array}$ & $\begin{array}{c}-319.73 \\
{[221.027]}\end{array}$ \\
\hline High Conflict Dummy & & $\begin{array}{l}1.66^{* * *} \\
{[0.206]} \\
\end{array}$ & $\begin{array}{c}9.31 \\
{[9.188]} \\
\end{array}$ & $\begin{array}{c}1.66^{* * * *} \\
{[0.217]} \\
\end{array}$ & $\begin{array}{l}2.31 * * \\
{[0.539]}\end{array}$ & $\begin{array}{l}2.32 * * \\
{[0.537]} \\
\end{array}$ \\
\hline Primary $\times$ High Conflict & & & $\begin{array}{c}-1.75 \\
{[2.071]}\end{array}$ & & & \\
\hline Natural Resource Rents & & $\begin{array}{c}0.14 \\
{[0.157]}\end{array}$ & $\begin{array}{c}0.45 \\
{[0.425]} \\
\end{array}$ & $\begin{array}{c}0.12 \\
{[0.331]}\end{array}$ & $\begin{array}{c}0.78^{*} \\
{[0.275]}\end{array}$ & $\begin{array}{c}0.83 \\
{[0.368]} \\
\end{array}$ \\
\hline Democracy & & $\begin{array}{c}0.56 \\
{[0.430]}\end{array}$ & $\begin{array}{c}0.62 \\
{[0.382]}\end{array}$ & $\begin{array}{c}0.53 \\
{[0.282]}\end{array}$ & $\begin{array}{c}0.96 \\
{[0.502]}\end{array}$ & $\begin{array}{c}1.01 * \\
{[0.407]}\end{array}$ \\
\hline Income Inequality & & $\begin{array}{c}11.04 * \\
{[3.795]}\end{array}$ & $\begin{array}{c}11.63 * * \\
{[3.279]}\end{array}$ & $\begin{array}{c}7.08 \\
{[27.873]} \\
\end{array}$ & $\begin{array}{c}10.37 * * \\
{[3.082]}\end{array}$ & $\begin{array}{c}17.34 \\
{[26.647]}\end{array}$ \\
\hline Urbanization & & $\begin{array}{c}-0.38 \\
{[0.539]} \\
\end{array}$ & $\begin{array}{c}0.82 \\
{[1.786]} \\
\end{array}$ & $\begin{array}{c}-0.35 \\
{[0.489]} \\
\end{array}$ & $\begin{array}{c}-5.43 \\
{[3.902]} \\
\end{array}$ & $\begin{array}{c}-5.53 \\
{[3.814]} \\
\end{array}$ \\
\hline Inflation & & $\begin{array}{c}-0.05 \\
{[0.148]}\end{array}$ & $\begin{array}{c}0.04 \\
{[0.235]}\end{array}$ & $\begin{array}{c}-0.05 \\
{[0.175]}\end{array}$ & $\begin{array}{c}-0.18 \\
{[0.165]}\end{array}$ & $\begin{array}{c}-0.18 \\
{[0.171]}\end{array}$ \\
\hline Youth Bulge & & $\begin{array}{l}28.61 * \\
{[9.457]}\end{array}$ & $\begin{array}{c}3.5 \\
{[24.462]} \\
\end{array}$ & $\begin{array}{c}26.26 \\
{[27.664]} \\
\end{array}$ & $\begin{array}{c}-414.12 \\
{[294.569]}\end{array}$ & $\begin{array}{c}-414.78 \\
{[301.689]}\end{array}$ \\
\hline Primary $\times$ Inequality & & & & $\begin{array}{c}1.01 \\
{[8.085]}\end{array}$ & & $\begin{array}{c}-1.78 \\
{[7.557]} \\
\end{array}$ \\
\hline Primary $\times$ Youth Bulge & & & & & $\begin{array}{c}113.12 \\
{[74.456]}\end{array}$ & $\begin{array}{c}114.34 \\
{[76.197]}\end{array}$ \\
\hline Constant & $\begin{array}{c}2.5 \\
{[2.294]} \\
\end{array}$ & $\begin{array}{c}-138.83 * * * \\
{[17.079]} \\
\end{array}$ & $\begin{array}{c}-70.18 \\
{[74.914]}\end{array}$ & $\begin{array}{c}-117.41 \\
{[177.862]} \\
\end{array}$ & $\begin{array}{c}1134.73 \\
{[841.902]}\end{array}$ & $\begin{array}{c}1110.99 \\
{[879.794]}\end{array}$ \\
\hline Number of Observation & 131 & 45 & 45 & 45 & 45 & 45 \\
\hline$R$-Squared & 0.292 & 0.871 & 0.876 & 0.871 & 0.898 & 0.898 \\
\hline Number of Countries & 22 & 12 & 12 & 12 & 12 & 12 \\
\hline
\end{tabular}

${ }^{* * *} p<0.01,{ }^{* *} p<0.05, * p<0.1$; Robust standard errors in brackets. Year dummies included in all models but not reported here. All explanatory variables, except GINI, are lagged by one period. In addition, all variables including CIVTOT are logged to the base ten.

In Table 6 where secondary schooling is the principal explanatory variable, the results in Model 1 show that secondary schooling is a strong driver of conflict intensity in Africa. Ironically, the positive influence of secondary schooling on conflict increases in magnitude (though reducing in statistical significance) after controlling for our full set of conditioning variables (Model 2). Model 2 results further tell us that conditioning on secondary schooling; inequality and urbanization are significant drivers of conflict while youth bulge reduces conflict. As noted before, the positive statistically significant sign on the high conflict dummy (HIGHCON) suggests that secondary schooling might impact on conflict differently in high and low conflict environments. The next step thus involves interacting secondary 
schooling with HIGHCON (Model 3), urbanization (Model 4), inequality (Model 5) and youth bulge (Model 6) controlling for the full set of conditioning variables.

Table 6. Fixed effects results on secondary schooling.

\begin{tabular}{|c|c|c|c|c|c|c|c|}
\hline \multicolumn{8}{|c|}{ DEPENDENT VARIABLE: CONFLICT INTENSITY } \\
\hline & Model 1 & Model 2 & Model 3 & Model 4 & Model 5 & Model 6 & Model 7 \\
\hline \multirow{2}{*}{ Conflict Intensity (Lagged) } & 0.13 & 0.24 & 0.21 & 0.24 & 0.31 & 0.29 & 0.8 \\
\hline & {$[0.126]$} & {$[0.174]$} & {$[0.200]$} & {$[0.199]$} & {$[0.435]$} & {$[0.190]$} & {$[0.552]$} \\
\hline \multirow{2}{*}{ Secondary Enrolment } & $1.49^{* *}$ & $6.02 *$ & 6.02 & $18.86^{* *}$ & -20.83 & -25.99 & -141.81 \\
\hline & {$[0.332]$} & [2.408] & {$[2.772]$} & {$[4.382]$} & [88.961] & [13.556] & [87.084] \\
\hline \multirow{2}{*}{ High Conflict Dummy } & & $2.50 * *$ & $3.83^{* * *}$ & $2.20^{* *}$ & 2.83 & $2.53^{* *}$ & 3.68 \\
\hline & & {$[0.730]$} & {$[0.584]$} & {$[0.669]$} & [1.795] & {$[0.696]$} & {$[2.066]$} \\
\hline \multirow{2}{*}{ Secondary $\times$ High Conflict } & & & -0.48 & & & & 0.09 \\
\hline & & & [0.401] & & & & {$[0.895]$} \\
\hline \multirow{2}{*}{ Natural Resource Rents } & & 0.64 & $0.94 * *$ & $1.04^{*}$ & 0.36 & $0.86^{* * *}$ & -0.11 \\
\hline & & {$[0.272]$} & {$[0.245]$} & {$[0.345]$} & {$[0.943]$} & {$[0.144]$} & {$[0.921]$} \\
\hline \multirow{2}{*}{ Urbanization } & & $6.24^{*}$ & $7.86^{*}$ & $22.62 * * *$ & 4.52 & $7.82 *$ & $45.02 *$ \\
\hline & & {$[2.307]$} & {$[3.252]$} & {$[1.594]$} & {$[8.465]$} & {$[2.556]$} & {$[15.836]$} \\
\hline \multirow{2}{*}{ Income Inequality } & & $12.71 * * *$ & $12.95 * * *$ & $10.53 * * *$ & -6.78 & $12.75 * * *$ & -30.53 \\
\hline & & {$[0.757]$} & [0.991] & {$[0.952]$} & [65.995] & [1.099] & {$[77.366]$} \\
\hline \multirow{2}{*}{ Inflation } & & -0.73 & -0.59 & -0.76 & -0.87 & -0.77 & -1.77 \\
\hline & & {$[0.494]$} & {$[0.653]$} & {$[0.579]$} & {$[0.925]$} & {$[0.553]$} & {$[1.336]$} \\
\hline \multirow{2}{*}{ Youth Bulge } & & $-118.98 * *$ & $-150.26^{* * *}$ & $-117.25^{*}$ & -149.58 & $-163.12 * * *$ & $-321.95 *$ \\
\hline & & {$[36.050]$} & {$[21.552]$} & [40.292] & [122.439] & {$[20.348]$} & [110.444] \\
\hline \multirow{2}{*}{ Democracy } & & 0.97 & 0.63 & 1.05 & 1.29 & 1 [1 & 3.49 \\
\hline & & {$[1.166]$} & {$[1.462]$} & [1.246] & [2.221] & $1[1.220]$ & [2.877] \\
\hline
\end{tabular}

\section{Secondary $\times$ Resource Rents}

\begin{tabular}{|c|c|c|c|c|c|c|c|}
\hline Secondary $\times$ Urbanization & & & & $\begin{array}{c}-5.15^{* * *} \\
{[0.570]} \\
\end{array}$ & & & $\begin{array}{l}-16.07 \\
{[8.143]}\end{array}$ \\
\hline Secondary $\times$ Inequality & & & & & $\begin{array}{c}7.95 \\
{[26.909]} \\
\end{array}$ & & $\begin{array}{c}55.64 \\
{[30.983]} \\
\end{array}$ \\
\hline Secondary $\times$ Youth Bulge & & & & & & $\begin{array}{l}11.56^{*} \\
{[4.500]}\end{array}$ & \\
\hline Constant & $\begin{array}{c}-0.72 \\
{[1.676]} \\
\end{array}$ & $\begin{array}{c}282.94 * \\
{[100.748]}\end{array}$ & $\begin{array}{c}372.73 * * * \\
{[62.915]}\end{array}$ & $\begin{array}{c}245.75 \\
{[107.180]}\end{array}$ & $\begin{array}{c}438.53 \\
{[584.977]} \\
\end{array}$ & $\begin{array}{c}399.48 * * * \\
{[53.576]}\end{array}$ & $\begin{array}{c}1244.50 \\
{[536.418]}\end{array}$ \\
\hline Observations & 116 & 39 & 39 & 39 & 39 & 39 & 39 \\
\hline$R$-Squared & 0.373 & 0.932 & 0.936 & 0.938 & 0.933 & 0.934 & 0.955 \\
\hline Number of Countries & 22 & 12 & 12 & 12 & 12 & 12 & 12 \\
\hline
\end{tabular}

*** $p<0.01,{ }^{* *} p<0.05, * p<0.1$; Robust standard errors in brackets. Year dummies included in all models but not reported here. All explanatory variables, except GINI, are lagged by one period. In addition, all variables including CIVTOT are logged to the base ten. 
Two key channels of transmission emerge from this exercise namely, urbanization and youth bulge although they exert opposite effects on the education-conflict nexus. Following Model 5 results, although secondary schooling and urbanization generally raise the conflict intensity, in environments where the urbanization rate (secondary schooling) is high, secondary schooling (urbanization) is found to have a strong mitigating impact on conflict. The intuition for this result could be that urbanization working through enhanced productivity (presumably the product of secondary education) helps reduce conflict, which is consistent with Collier and Hoeffler (2004) [19] finding.

Although the results in Model 6 suggest that secondary schooling and youth bulge each have mitigating impacts on conflict, in environments with high youth bulges (high secondary schooling), secondary schooling (youth bulge) raises conflict. This result is entirely consistent with prior empirical evidence which suggests that low education levels increase the risk of conflict in contexts where youth bulge is high.

In Table 7 where tertiary schooling is the principal explanatory variable, the results in Models 1 and 2 show that tertiary schooling has a positive but statistically insignificant effect on conflict in Africa. Model 2 results further tell us that conditioning on tertiary schooling; urbanization, inequality, youth bulge and inflation are significant drivers of conflict while democratization mitigates conflict. The next step thus involves interacting tertiary schooling with inequality (Model 3), urbanization (Model 4), youth bulge (Model 5) and inflation (Model 6) controlling as usual, for the full set of conditioning variables.

Only one channel of transmission appears to mediate between tertiary schooling and conflict: income inequality. Following Model 3 results, although tertiary schooling and inequality generally tend to increase conflicts, in environments where inequality (tertiary schooling) is high, tertiary schooling (inequality) is found to have a strong mitigating impact on conflict. The intuition for this result as Murshed (2002) [55] and Oyefusi (2008) [8] also suggest, could be that higher education helps people to peacefully resolve their differences through formal institutional channels rather than by resorting to violence. This finding contradicts the recommendations from prior empirical studies, notably by Thyne (2006) [5] which cautions against disproportionate public investment in favor of tertiary education suggesting that this would likely ignite conflicts by widening the inequality gap between the rich and the poor. 
Table 7. Fixed effects results on tertiary schooling.

\begin{tabular}{|c|c|c|c|c|c|c|c|}
\hline \multicolumn{8}{|c|}{ Dependent Variable: Conflict Intensity } \\
\hline & Model 1 & Model 2 & Model 3 & Model 4 & Model 5 & Model 6 & Model 7 \\
\hline Conflict Intensity (Lagged) & $\begin{array}{l}0.20^{* *} \\
{[0.061]}\end{array}$ & $\begin{array}{l}-0.51^{* *} \\
{[0.113]}\end{array}$ & $\begin{array}{c}-0.70 * * * \\
{[0.038]}\end{array}$ & $\begin{array}{l}-0.51 * * \\
{[0.113]}\end{array}$ & $\begin{array}{l}-0.52^{* *} \\
{[0.097]}\end{array}$ & $\begin{array}{l}-0.50^{* *} \\
{[0.111]}\end{array}$ & $\begin{array}{l}-0.52 * * \\
{[0.105]}\end{array}$ \\
\hline Tertiary Enrolment & $\begin{array}{c}0.14 \\
{[0.327]}\end{array}$ & $0.16[0.515]$ & $\begin{array}{c}43.44^{*} \\
{[14.826]}\end{array}$ & $0.13[0.376]$ & 3.32 [6.462] & $\begin{array}{c}-0.01 \\
{[0.299]}\end{array}$ & $0.2[0.497]$ \\
\hline High Conflict Dummy & & $0.15[0.104]$ & $0.1[0.047]$ & $0.15[0.120]$ & $0.12[0.152] 0$ & $0.16[0.103]$ & $\begin{array}{c}0.21 * \\
{[0.074]}\end{array}$ \\
\hline Tertiary $\times$ Inequality & & & $\begin{array}{c}-12.78 * \\
{[4.292]}\end{array}$ & & & & \\
\hline Natural Resource Rents & & $0.06[0.030]$ & $\begin{array}{l}0.60^{* *} \\
{[0.184]} \\
\end{array}$ & $0.04[0.053]$ & $\begin{array}{c}0.04 * \\
{[0.016]}\end{array}$ & $0.07[0.036]$ & $\begin{array}{c}-0.01 \\
{[0.010]}\end{array}$ \\
\hline Urbanization & & $\begin{array}{l}8.97 * * * \\
{[0.449]}\end{array}$ & $\begin{array}{c}12.14 * * * \\
{[0.781]}\end{array}$ & $\begin{array}{l}8.91 * * * \\
{[0.828]}\end{array}$ & $\begin{array}{l}8.77^{* * *} \\
{[0.823]}\end{array}$ & $\begin{array}{l}8.81 * * * \\
{[0.665]}\end{array}$ & $\begin{array}{l}8.18 * * * \\
{[0.766]}\end{array}$ \\
\hline Income Inequality & & $\begin{array}{l}5.13^{* *} \\
{[1.181]}\end{array}$ & $\begin{array}{l}2.16^{* *} \\
{[0.532]} \\
\end{array}$ & $\begin{array}{l}5.16^{* *} \\
{[1.372]} \\
\end{array}$ & $\begin{array}{l}5.21 * * \\
{[1.314]}\end{array}$ & $\begin{array}{l}5.39 * * \\
{[1.452]}\end{array}$ & $\begin{array}{l}5.16^{* *} \\
{[1.165]}\end{array}$ \\
\hline Youth Bulge & & $\begin{array}{c}15.58 * * * \\
{[6.792]} \\
\end{array}$ & $\begin{array}{c}179.26^{* * *} \\
{[17.569]} \\
\end{array}$ & $\begin{array}{c}115.49 * * * \\
{[7.477]} \\
\end{array}$ & $\begin{array}{c}114.61 * * * \\
{[8.553]} \\
\end{array}$ & $\begin{array}{c}108.40 * * * \\
{[16.383]} \\
\end{array}$ & $\begin{array}{c}120.36^{* * *} \\
{[4.615]} \\
\end{array}$ \\
\hline Inflation & & $\begin{array}{l}0.23^{* *} \\
{[0.069]}\end{array}$ & $\begin{array}{c}0.38 * * * \\
{[0.009]}\end{array}$ & $\begin{array}{l}0.23 * * \\
{[0.072]}\end{array}$ & $\begin{array}{l}0.24 * * \\
{[0.053]}\end{array}$ & $\begin{array}{c}0.22 * \\
{[0.073]}\end{array}$ & $\begin{array}{c}0.26^{* *} \\
{[0.058]}\end{array}$ \\
\hline Democracy & & $\begin{array}{c}-1.27 * * * \\
{[0.150]}\end{array}$ & $\begin{array}{c}-1.42 * * * \\
{[0.065]}\end{array}$ & $\begin{array}{c}-1.26^{* *} \\
{[0.217]}\end{array}$ & $\begin{array}{c}-1.25 * * * \\
{[0.185]}\end{array}$ & $\begin{array}{c}-1.27 * * * \\
{[0.139]}\end{array}$ & $\begin{array}{l}-1.02^{* *} \\
{[0.257]}\end{array}$ \\
\hline Tertiary $\times$ Urbanization & & & & $\begin{array}{c}0 \\
{[0.025]}\end{array}$ & & & \\
\hline Tertiary $\times$ Youth Bulge & & & & & $\begin{array}{c}-1.11 \\
{[2.102]}\end{array}$ & & \\
\hline Tertiary $\times$ Inflation & & & & & & $0.03[0.036]$ & \\
\hline Tertiary $\times$ Democracy & & & & & & & $\begin{array}{c}-0.11 \\
{[0.049]}\end{array}$ \\
\hline Constant & $\begin{array}{c}1.20^{*} \\
{[0.474]}\end{array}$ & $\begin{array}{c}-370.03 * * * \\
{[15.833]}\end{array}$ & $\begin{array}{c}-551.48 * * * \\
{[51.824]}\end{array}$ & $\begin{array}{c}-369.68 * * * \\
{[18.242]}\end{array}$ & $\begin{array}{c}-367.01 * * *- \\
{[21.477]}\end{array}$ & $\begin{array}{c}-353.66 * * * \\
{[44.080]}\end{array}$ & $\begin{array}{c}-384.53 * * * \\
{[10.053]}\end{array}$ \\
\hline Observations & 98 & 37 & 37 & 37 & 37 & 37 & 37 \\
\hline$R$-Squared & 0.399 & 0.994 & 0.995 & 0.994 & 0.994 & 0.994 & 0.994 \\
\hline Number of Countries & 17 & 10 & 10 & 10 & 10 & 10 & 10 \\
\hline
\end{tabular}

*** $p<0.01, * * p<0.05, * p<0.1$; Robust standard errors in brackets. Year dummies included in all models but not reported here. All explanatory variables, except GINI, are lagged by one period. In addition, all variables including CIVTOT are logged to the base ten.

\subsection{Robustness Checks Using GMM Estimation}

We noted earlier that reverse causality is a major concern associated with the estimation of equation (1) above and we attempted to address the problem by using lagged independent variables. However, this might not sufficiently address the underlying endogeneity problems linked with the fact that conflict generally impacts negatively on education either by hampering school attendance or causing brain drain. Therefore, as robustness check on the fixed effects results obtained above, we employ a GMM estimation 
technique, which best handles endogeneity problems. We follow the same empirical strategy as with the fixed effects models and report the results in Tables 8-10.

Table 8. GMM results on primary schooling.

\begin{tabular}{|c|c|c|c|c|c|}
\hline \multicolumn{6}{|c|}{ Dependent Variable: Conflict Intensity } \\
\hline & Model 1 & Model 2 & Model 3 & Model 4 & Model 5 \\
\hline \multirow{2}{*}{ Conflict Intensity (Lagged) } & $0.28 * * *$ & $0.30 * * *$ & $0.32 * * *$ & $0.30 * * *$ & $0.32 * * *$ \\
\hline & {$[0.017]$} & {$[0.007]$} & {$[0.010]$} & {$[0.007]$} & {$[0.011]$} \\
\hline \multirow{2}{*}{ Primary Enrolment } & -0.13 & -0.13 & -0.66 & -0.03 & -0.59 \\
\hline & {$[0.578]$} & {$[0.527]$} & {$[0.516]$} & {$[0.533]$} & {$[0.548]$} \\
\hline \multirow{2}{*}{ Primary $\times$ Resource Rents } & & & $0.03 * * *$ & & $0.03 * * *$ \\
\hline & & & {$[0.010]$} & & {$[0.011]$} \\
\hline \multirow{2}{*}{ Natural Resource Rents } & & $0.53^{*}$ & $-2.00 * *$ & $0.53^{*}$ & $-1.96^{*}$ \\
\hline & & {$[0.308]$} & {$[0.952]$} & {$[0.311]$} & {$[1.007]$} \\
\hline \multirow{2}{*}{ Democracy } & & -0.03 & -0.03 & -0.04 & -0.04 \\
\hline & & {$[0.187]$} & {$[0.186]$} & {$[0.177]$} & {$[0.175]$} \\
\hline \multirow{2}{*}{ Income inequality } & & 1.33 & 1.21 & 1.28 & 1.15 \\
\hline & & {$[0.867]$} & {$[0.873]$} & {$[0.853]$} & {$[0.861]$} \\
\hline \multirow{2}{*}{ Urbanization } & & 1.29 & 0.16 & 1.25 & 0.15 \\
\hline & & [2.004] & {$[1.760]$} & {$[1.998]$} & {$[1.753]$} \\
\hline \multirow{2}{*}{ Inflation } & & 0 & 0 & 0 & 0 \\
\hline & & {$[0.001]$} & {$[0.001]$} & {$[0.001]$} & {$[0.001]$} \\
\hline \multirow{2}{*}{ Youth Bulge } & & 15.39 & 16.38 & 15.82 & 16.62 \\
\hline & & {$[18.991]$} & {$[18.633]$} & {$[19.936]$} & {$[19.567]$} \\
\hline \multirow{2}{*}{ High Conflict Dummy } & & $22.50 *$ & $24.15^{* *}$ & 32.67 & 31.25 \\
\hline & & {$[11.849]$} & {$[11.810]$} & {$[31.868]$} & [31.945] \\
\hline \multirow{2}{*}{ Primary $\times$ High Conflict } & & & & -0.12 & -0.09 \\
\hline & & & & {$[0.260]$} & {$[0.260]$} \\
\hline \multirow{2}{*}{ Constant } & 43.02 & -359.04 & -325.89 & -373.4 & -345.83 \\
\hline & {$[45.154]$} & {$[390.881]$} & {$[380.529]$} & [424.232] & [415.542] \\
\hline Observations & 359 & 309 & 309 & 309 & 309 \\
\hline Number of Countries & 25 & 22 & 22 & 22 & 22 \\
\hline
\end{tabular}

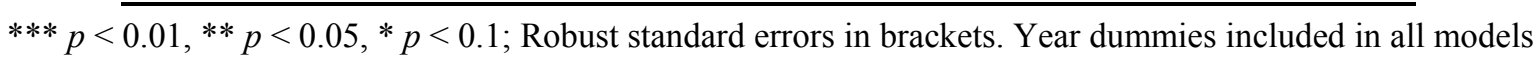
but not reported here. 
Table 9. GMM results on secondary schooling.

\begin{tabular}{|c|c|c|c|c|c|}
\hline \multicolumn{6}{|c|}{ Dependent Variable: Conflict Intensity } \\
\hline & Model 1 & Model 2 & Model 3 & Model 4 & Model 5 \\
\hline \multirow{2}{*}{ Conflict Intensity (Lagged) } & $0.30 * * *$ & $0.34 * * *$ & $0.34 * * *$ & $0.33 * * *$ & $0.33 * * *$ \\
\hline & {$[0.034]$} & {$[0.012]$} & {$[0.011]$} & {$[0.014]$} & {$[0.014]$} \\
\hline \multirow{2}{*}{ Secondary Enrolment } & 3.75 & -0.55 & -0.51 & 1.08 & 1.11 \\
\hline & {$[2.992]$} & {$[0.949]$} & {$[0.954]$} & {$[2.691]$} & {$[2.715]$} \\
\hline \multirow{2}{*}{ Secondary $\times$ High Conflict } & & & -0.12 & & -0.11 \\
\hline & & & {$[0.186]$} & & {$[0.178]$} \\
\hline \multirow{2}{*}{ High Conflict Dummy } & & $12.96 * *$ & 15.58 & $12.86^{* *}$ & 15.21 \\
\hline & & {$[6.484]$} & {$[9.487]$} & {$[6.478]$} & {$[9.306]$} \\
\hline \multirow{2}{*}{ Natural Resource Rents } & & 0.33 & 0.33 & 0.33 & 0.34 \\
\hline & & {$[0.311]$} & {$[0.312]$} & {$[0.323]$} & {$[0.324]$} \\
\hline \multirow{2}{*}{ Urbanization } & & $2.11 * *$ & $2.09 * *$ & 6.58 & 6.53 \\
\hline & & {$[0.958]$} & {$[0.955]$} & {$[6.481]$} & {$[6.454]$} \\
\hline \multirow{2}{*}{ Income Inequality } & & 1.08 & 1.08 & 1.02 & 1.03 \\
\hline & & {$[0.728]$} & {$[0.726]$} & {$[0.732]$} & {$[0.729]$} \\
\hline \multirow{2}{*}{ Inflation } & & 0 & 0 & 0 & 0 \\
\hline & & {$[0.000]$} & {$[0.000]$} & {$[0.000]$} & {$[0.000]$} \\
\hline \multirow{2}{*}{ Youth Bulge } & & 11.86 & 11.56 & 13.84 & 13.58 \\
\hline & & {$[21.078]$} & {$[21.021]$} & {$[20.118]$} & {$[20.021]$} \\
\hline \multirow{2}{*}{ Democracy } & & -0.15 & -0.15 & -0.14 & -0.15 \\
\hline & & {$[0.109]$} & {$[0.110]$} & {$[0.103]$} & {$[0.104]$} \\
\hline \multirow{2}{*}{ Secondary $\times$ Urbanization } & & & & -0.43 & -0.43 \\
\hline & & & & {$[0.608]$} & {$[0.607]$} \\
\hline \multirow{2}{*}{ Constant } & -46.8 & -265.55 & -260.81 & -324.7 & -320.42 \\
\hline & [58.960] & {$[400.265]$} & [399.141] & {$[375.516]$} & {$[373.748]$} \\
\hline Observations & 286 & 244 & 244 & 244 & 244 \\
\hline Number of Countries & 25 & 22 & 22 & 22 & 22 \\
\hline
\end{tabular}

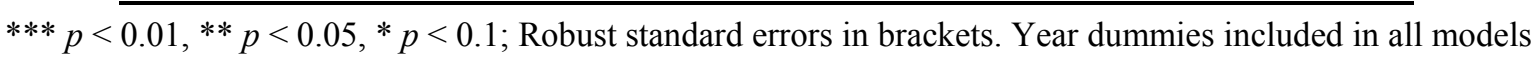
but not reported here. 
Table 10. GMM results on tertiary schooling.

\begin{tabular}{|c|c|c|c|c|c|c|}
\hline \multicolumn{7}{|c|}{ Dependent Variable: Conflict Intensity } \\
\hline & Model 1 & Model 2 & Model 3 & Model 4 & Model 5 & Model 6 \\
\hline Conflict Intensity (Lagged) & $\begin{array}{c}0.29 * * * \\
{[0.014]}\end{array}$ & $\begin{array}{l}0.31^{* * * *} \\
{[0.004]}\end{array}$ & $\begin{array}{c}0.31^{* * *} \\
{[0.004]}\end{array}$ & $\begin{array}{c}0.31^{* * *} \\
{[0.006]}\end{array}$ & $\begin{array}{c}0.31 * * * \\
{[0.005]}\end{array}$ & $\begin{array}{c}0.31 * * * \\
{[0.007]}\end{array}$ \\
\hline Tertiary Enrolment & $\begin{array}{c}12.46^{* * *} \\
{[4.837]} \\
\end{array}$ & $\begin{array}{c}-2.78 \\
{[3.172]}\end{array}$ & $\begin{array}{l}-4.23 * \\
{[2.491]}\end{array}$ & $\begin{array}{c}6.58 \\
{[10.278]} \\
\end{array}$ & $\begin{array}{c}19.28 \\
{[16.957]}\end{array}$ & $\begin{array}{c}19.38 \\
{[18.760]}\end{array}$ \\
\hline Tertiary $\times$ High Conflict & & & $\begin{array}{c}-2.20 * * \\
{[1.123]} \\
\end{array}$ & & & $\begin{array}{c}-1.60^{* *} \\
{[0.712]} \\
\end{array}$ \\
\hline Tertiary $\times$ Urbanization & & & & $\begin{array}{c}-3.49 \\
{[3.530]}\end{array}$ & & $\begin{array}{c}-2.81 \\
{[3.074]}\end{array}$ \\
\hline Tertiary $\times$ Inequality & & & & & $\begin{array}{c}-0.58 \\
{[0.431]} \\
\end{array}$ & $\begin{array}{c}-0.4 \\
{[0.358]}\end{array}$ \\
\hline Tertiary $\times$ Democracy & & & & & & $\begin{array}{c}0.03 \\
{[0.038]}\end{array}$ \\
\hline High Conflict Dummy & & $\begin{array}{l}13.07^{* *} \\
{[5.723]}\end{array}$ & $\begin{array}{c}21.71^{* * *} \\
{[8.113]} \\
\end{array}$ & $\begin{array}{l}13.11^{* *} \\
{[5.308]} \\
\end{array}$ & $\begin{array}{l}14.25^{* *} \\
{[6.050]}\end{array}$ & $\begin{array}{c}20.50^{* * *} \\
{[7.344]} \\
\end{array}$ \\
\hline Natural Resource Rents & & $\begin{array}{c}0.02 \\
{[0.349]}\end{array}$ & $\begin{array}{c}0.06 \\
{[0.350]}\end{array}$ & $\begin{array}{c}-0.14 \\
{[0.456]}\end{array}$ & $\begin{array}{c}-0.04 \\
{[0.385]}\end{array}$ & $\begin{array}{c}-0.18 \\
{[0.492]}\end{array}$ \\
\hline Urbanization & & $\begin{array}{l}4.78^{* *} \\
{[2.140]}\end{array}$ & $\begin{array}{l}4.54 * * \\
{[2.113]}\end{array}$ & $\begin{array}{l}7.31 * * * \\
{[2.062]}\end{array}$ & $\begin{array}{c}3.9 \\
{[2.384]}\end{array}$ & $\begin{array}{l}6.05^{* * *} \\
{[1.655]}\end{array}$ \\
\hline Income Inequality & & $\begin{array}{c}2.31 * \\
{[1.263]} \\
\end{array}$ & $\begin{array}{c}2.27^{*} \\
{[1.235]} \\
\end{array}$ & $\begin{array}{c}1.86^{*} \\
{[0.982]} \\
\end{array}$ & $\begin{array}{c}3.52 * \\
{[2.010]}\end{array}$ & $\begin{array}{c}2.74 * \\
{[1.588]} \\
\end{array}$ \\
\hline Inflation & & $\begin{array}{c}0 \\
{[0.000]}\end{array}$ & $\begin{array}{c}0 \\
{[0.000]}\end{array}$ & $\begin{array}{c}0 \\
{[0.000]} \\
\end{array}$ & $\begin{array}{c}0 \\
{[0.000]}\end{array}$ & $\begin{array}{c}0 \\
{[0.000]}\end{array}$ \\
\hline Youth Bulge & & $\begin{array}{c}24.14 \\
{[16.295]}\end{array}$ & $\begin{array}{c}26.27 \\
{[16.808]}\end{array}$ & $\begin{array}{c}19.24 \\
{[13.505]}\end{array}$ & $\begin{array}{c}25.91 \\
{[17.074]}\end{array}$ & $\begin{array}{c}23.41 \\
{[15.039]}\end{array}$ \\
\hline Democracy & & $\begin{array}{l}-0.15^{*} \\
{[0.087]}\end{array}$ & $\begin{array}{c}-0.18^{* *} \\
{[0.088]}\end{array}$ & $\begin{array}{l}-0.17^{*} \\
{[0.100]} \\
\end{array}$ & $\begin{array}{l}-0.16^{*} \\
{[0.088]}\end{array}$ & $\begin{array}{l}-0.27^{*} \\
{[0.160]}\end{array}$ \\
\hline Constant & $\begin{array}{c}-12.35 \\
{[29.790]}\end{array}$ & $\begin{array}{l}-584.09 * \\
{[331.295]} \\
\end{array}$ & $\begin{array}{l}-616.54 * \\
{[337.724]} \\
\end{array}$ & $\begin{array}{l}-476.12 * \\
{[265.168]} \\
\end{array}$ & $\begin{array}{c}-665.97 * \\
{[371.147]} \\
\end{array}$ & $\begin{array}{l}-577.35^{*} \\
{[306.530]}\end{array}$ \\
\hline Observations & 233 & 196 & 196 & 196 & 196 & 196 \\
\hline Number of Countries & 25 & 21 & 21 & 21 & 21 & 21 \\
\hline
\end{tabular}

The results in Table 8 where primary schooling is the principal explanatory variable suggests that primary schooling broadly has a mitigating impact on conflicts in Africa, though its effect is not statistically significant. Model 2 results suggest that, conditioning on primary schooling, natural resource rents are a significant driver of conflicts in Africa. However, when primary schooling is interacted with natural resource rents in Model 3, natural resource rents assume a pacifying effect on conflict. Perhaps more interestingly, the interaction between primary schooling and natural resource rents further suggests that, although primary schooling generally has a pacifying effect on conflict, it could ignite conflicts in environments with high natural resource rents, as prior empirical evidence has suggested. This finding 
concurs with the fixed effects results presented in Table 5 in one main aspect: primary schooling broadly reduces not ignites conflicts.

Table 8 results where secondary schooling is the principal explanatory variable partially concurs with our fixed effects results presented in Table 6: that secondary schooling drives conflicts in Africa, although this impact is not statistically significant in the GMM models. Further consistent with the fixed effects results in Table 6, urbanization is a significant driver of conflicts in Africa. Furthermore, and in line with our fixed effects results, the GMM results in Models 4 and 5 do suggest that although secondary schooling and urbanization potentially drives conflicts, in environments where secondary schooling (urbanization) is high, urbanization (secondary schooling) mitigates conflicts.

Table 10 results where tertiary schooling is the principal explanatory variable largely concurs with our fixed effects results presented in Model 2 in two key aspects: (1) tertiary education does not have a direct significant positive impact on conflicts, which is also consistent with Thyne (2006) [5], (2) although tertiary schooling and inequality generally tend to increase conflicts, in environments where inequality (tertiary schooling) is high, tertiary schooling (inequality) mitigates conflict. This effect is however not statistically significant as observed in the fixed effects model (see Model 5). Two other important findings are worth reporting from the GMM estimation results: (1) although tertiary schooling (urbanization) drive conflicts in Africa, in environments where tertiary schooling (urbanization) is high, urbanization (tertiary schooling) mitigates conflicts (Model 4). This impact is however not statistically significant. (2) Although democratization mitigates conflicts, in environments where tertiary schooling is high, democratization might spur conflicts. Also, this impact is not statistically significant.

\section{Summary and Conclusion}

The main endeavor of this study has been to investigate the impact of different education levels (primary, secondary and tertiary), on the intensity of intra-state conflicts in Africa. To attain this objective, the empirical strategy sought to achieve two goals: (1) that of ascertaining the likely impact of each schooling dimension on conflict intensity and (2) that of determining the likely channels of transmission between the relevant schooling dimension and conflict intensity. Annual data during 1989-2008 for 25 African countries was utilized as well as fixed-effects regressions with clustered standard errors in a panel data framework. A robustness check using a one-step GMM estimation technique allowed us to draw the following conclusions:

1 Primary schooling broadly mitigates conflicts in Africa. However, in environments with high natural resource rents, it could ignite conflicts. This finding is consistent with prior empirical evidence notably by Barakat and Urdal (2009) [3] which suggests that the risk of conflict is higher in countries where low education levels coincide with the presence of abundant natural resources rents.

2 There is evidence, although not overwhelming, that secondary schooling drives conflicts in Africa. There is also evidence that urbanization drives conflicts in Africa. However, although secondary schooling and urbanization potentially drives conflicts, in environments where secondary schooling (urbanization) is high, urbanization (secondary schooling) mitigates conflicts. The likely policy implication of this for African governments is that, in countries with a high level of urbanization, they should try to foster secondary education in order to reduce conflict. 
3 There is no evidence of a strong direct positive impact of tertiary education on conflicts in Africa, which is also consistent with Thyne (2006) [5]. Conditioning on tertiary schooling, income inequality appears to be a significant driver of conflicts in African states. However, in contexts where income inequality (tertiary schooling) is high, tertiary schooling (inequality) mitigates conflict. This finding somewhat contradicts the recommendations from Thyne (2006) [5] which cautions against disproportionate public investment in favor of tertiary education suggesting that this would likely ignite conflicts by widening the inequality gap between the rich and the poor. We argue that more investment in tertiary education (or more tertiary schooling to be more direct) is warranted in contexts where inequality levels are high, as this would enable folks to peacefully resolve their grievances or differences using formal institutional channels rather than by resorting to violence. The evidence in this study also lends partial support for African governments faced with high urbanization rates to continue investing in tertiary education as a conflict mitigation strategy.

As we conclude this paper, it is worthwhile highlighting two major limitations of our endeavor, beyond the traditional constrains linked to paucity of African time series data. First, while the present study demonstrates the differential impacts of different educational dimensions on conflict intensity, we are yet to fully understand the transmission mechanisms. Further research should probe this issue deeper. Second, the GMM model used as robustness checks faces the problem of proliferation of instruments or over-identification. Ideally, the use of data averages (non-overlapping intervals) instead of annual data would have been preferable but the change in data structure mandated by this approach would render the results non-comparable to the fixed effects model. Furthermore, there is the issue of whether a non-linear regression model would be more appropriate for use in this study given the fact that the UCDP conflict data is not continuous. We have largely avoided this concern by simply transforming discrete data into continuous data by means of calculating per capita number of battle deaths. Doing so, however, requires a strong theoretical justification; otherwise a non-linear estimation technique would be more appropriate. The problem with non-linear models is that one cannot easily use interaction terms. Further research should therefore suggest a more robust empirical model that handles these issues.

\section{Acknowledgments}

The research and financial support of Economic Research Southern Africa (ERSA) is hereby gratefully acknowledged.

\section{Conflicts of Interest}

The author declare no conflict of interest. 


\section{References}

1. World Bank. Lifelong Learning in the Global Knowledge Economy. Challenges for Developing Countries (Draft); World Bank: Washington, D.C., USA, 2002.

2. Østby, G.; Urdal, H. Education and Civil Conflict: A Review of the Quantitative Empirical Literature. Paper commissioned for the EFA Global Monitoring Report 2011, The Hidden Crisis: Armed Conflict and Education. Available online: http://unesdoc.unesco.org/images/0019/ 001907/190777e.pdf (accessed on 3 October 2015).

3. Barakat, B.; Henrik, U. Breaking the Waves? Does Education Mediate the Relationship Between Youth Bulges and Political Violence?; Policy Research Working Paper 5114; The World Bank: Washington, DC, USA, 2009.

4. Krueger, A.B.; Maleckova, J. Education, Poverty and Terrorism: Is There a Causal Connection? J. Econ. Perspect. 2003, 17, 119-144.

5. Thyne, C. ABC's, 123's, and the Golden Rule: The Pacifying Effect of Education on Civil War, 1980-1999. Int. Stud. Q. 2006, 50, 733-754.

6. Berrebi, C. Evidence about the Link Between Education, Poverty and Terrorism among Palestinians. Peace Econ. Peace Sci. Public Policy 2007, 13, 1-36.

7. Fair, C. The Educated Militants of Pakistan: Implications for Pakistan's Domestic Security. Contemp. South Asia 2008, 16, 93-106.

8. Oyefusi, A. Education, Studentship, and the Disposition to Civil Unrest among Youths in ResourceAbundant Regions: Evidence from Nigeria's Delta. Presented at the Conference on 'Youth Exclusion and Political Violence: Breaking the Link and Engaging Young People Positively in Development', Centre for the Study of Civil War (CSCW) at the Peace Research Institute, Oslo (PRIO), Norway, 4-6 December 2008.

9. Shayo, M. Education, Militarism and Civil Wars. Discussion Paper 07.03. Jerusalem: The Maurice Falk Institute for Economic Research in Israel. Available online: http://pluto.huji.ac.il/ $\sim$ mshayo/Education_and_Militarism.pdf (accessed on 3 October 2015).

10. Urdal, H. Population, Resources and Violent Conflict: A Sub-National Study of India 1956-2002. J. Confl. Resolut. 2008, 52, 590-617.

11. Bussmann, M. Gender Equality, Good Governance, and Peace. Presented at the General Polarization and Conflict (PAC) Meeting, Gaillac, France, 7-9 June 2007.

12. Besançon, M.L. Relative Resources: Inequality in Ethnic Wars, Revolutions, and Genocides. J. Peace Res. 2005, 42, 393-415.

13. Hegre, H. 2003. Disentangling Democracy and Development as Determinants of Armed Conflict. Presented at the Annual Meeting of International Studies Association, Portland, OR, USA, 27 February 2003.

14. Aryeetey, E.; Fosu, A. Explaining African Economic Growth Performance: The Case of Ghana. AERC Growth Working Paper, 7. Available online: http://www.researchgate.net/publication/ 265074393_Explaining_African_Economic_Growth_Performance_The_Case_of_Ghana (accessed on 3 October 2015).

15. Blomberg, S.B.; Hess, G.D.; Thacker, S. On the Conflict-Poverty Nexus. Econ. Politics 2006, 18, 237-267. 
16. Agbor, J.A. 2011. Does School Education Reduce the Likelihood of Societal Conflicts in Africa. Economic Research Southern Africa Working Paper No. 218. Available online: http://www.econrsa.org/system/files/publications/working_papers/wp218.pdf (accessed on 3 October 2015).

17. Gleditsch, N.P.; Wallensteen, P.; Eriksson, M.; Sollenberg, M.; Strand, H. Armed Conflict 19462001: A New Dataset. J. Peace Res. 2002, 39, 615-637.

18. Acemoglu, D.; Robinson, J.A. A Theory of Political Transitions. Am. Econ. Rev. 2001, 91, 938-963.

19. Collier, P.; Hoeffler, A. Greed and Grievance in Civil War. Oxf. Econ. Papers 2004, 56, 563-595.

20. Akoki, A.; Barbara, B.; Micheal, D.; Mmantetsa, M.; Alain, M.; Peter, M.; Patrick, M.; Pirella, P.; Harry, P.; Jee-Peng, T.; et al. Chapter 19: Education. Available online: http://info.worldbank.org/ etools/docs/library/81136/Nairobi2004/readings/ed/edprspsourcebookeng.pdf (accessed on 3 October 2015).

21. Alesina, A.; Perotti, R. Income Distribution, Political Instability, and Investment. Eur. Econ. Rev. 1996, 40, 1203-1228.

22. Hibbs, D. Mass Political Violence: A Cross-National Causal Analysis; Wiley: New York, NY, USA, 1973.

23. Huntington, S.P. Political Order in Changing Societies; Yale University Press: New Haven, CT, USA, 1968.

24. Becker, G.; Mulligan, C. On the Endogenous Determination of Time Preference. Q. J. Econ. 1997, 112, 729-758.

25. Becker, G. Accounting for Tastes; Harvard University Press: Cambridge, MA, USA, 1996.

26. Arrow, K. The Benefits of Education and the Formation of Preferences. In The Social Benefits of Education; Behrman, J., Stacey, N., Eds.; The Univeristy of Michigan Press: Ann Arbor, MI, USA, 1997; pp. 11-16.

27. Galor, O.; Moav, O. Das Human Kapital: A Theory of the Demise of the Class Structure. J. Rev. Econ. Stud. 2006, 73, 85-117.

28. Fedderke, J.W.; Kularatne, C. Characterizing Conflict Forms. Annual Bank Conference on Development Economics Working Paper. Available online: http://siteresources.worldbank.org/ DEC/Resources/84797-1284144259233/7386294-1284385904490/JohannesFedderke.pdf (accessed on 3 October 2015).

29. Bourguignon, F.; Verdier, T. The Political Economy of Education and Development in an Open Economy. Center of Economic Policy Research Working Paper 3075. Available online: http://www.cepr.org/active/publications/discussion_papers/dp.php?dpno=3075 (accessed on 3 October 2015).

30. Apter, D.E. The Gold Coast in Transition; Princeton University Press: Princeton, NJ, USA, 1955.

31. Foster, J.P. Education and Social Change in Ghana; Routledge and Kegan Paul: London, UK, 1965.

32. McWilliam, H.O.A.; Kwamena-Poh, M.A. The Development of Education in Ghana: An Outline; Longman Group Limited: London, UK, 1978.

33. Hirshleifer, J. Anarchy and its Breakdown. J. Polit. Econ. 1995, 103, $26-52$.

34. Bates, R.; Greif, A.; Singh, S. Organising Violence. J. Confl. Resolut. 2007, 46, 599-628.

35. Davies, L. Education and Conflict: Complexity and Chaos; Routledge: New York, NY, USA, 2004. 
36. Vriens, L. Responsibility for the Future: The Key to Peace Education; Publisher: City, Country, 2003; pp. 71-83.

37. Bush, K.; Saltarelli, D. The Two Faces of Education in Ethnic Conflict: Towards a Peace Building Education for Children; UNICEF Innocenti Research Centre: Florence, Italy, 2000.

38. Smith, A.; Vaux, T. Education, Conflict and International Development; Department for International Development: London, UK, 2003.

39. Urdal, H. A Clash of Generations? Youth Bulges and Political Violence. Int. Stud. Q. 2006, 50, 607-630.

40. Choucri, N. Population Dynamics and International Violence: Propositions, Insights and Evidence; DC Health: Lexington, MA, USA, 1974.

41. Goldstone, J.A. Demography, Environment, and Security; Diehl, P.F., Gleditsch, N.P., Eds.; Westview: Boulder, CO, USA, 2001.

42. Lia, B. Globalisation and the Future of Terrorism: Patterns and Predictions; Routledge: London, UK, 2005.

43. Boyden, J.; Ryder, P. Implementing the Right to Education in Areas of Armed Conflict. Available online: http://www.essex.ac.uk/armedcon/story_id/000454.pdf (accessed on 3 October 2015).

44. Lange, R. Promoting Livelihood and Employment in Post-conflict situations. Available online: www.enterprise-development.org/download.ashx?id=2091 (accessed on 3 October 2015).

45. Sommers, M. Youth: Care and Protection of Children in Emergencies: A Field Guide; Save the Children US: Washington, DC, USA, 2001.

46. Senghaas, D. Zivilisierung wider Willen. Der Konflikt der Kulturen mit sich selbst; Suhrkamp: Frankfurt, Germany, 1998.

47. Klaus, S.iWeltweite Bildung und soziale Ungleichheit. In Marianne Heimbach-Steins und Gerhard Kruip (Hg.); Bildung und Beteiligungsgerechtigkeit: Bielefeld, Germany, 2003; pp. 75-96.

48. Aguilar, P.; Richmond, M. Emergency Educational Response in the Rwandan Crisis. In Retamal and Aedo-Richmond; International Bureau of Education: Geneva, Switzerland, 1998; pp. 119-141.

49. Arellano, M.; Carrasco, R. Binary Choice Panel Data Models with Predetermined Variables. J. Econom. 2003, 115, 125-157.

50. Bates, R.H. Markets and States in Tropical Africa; University of California Press: Berkeley, CA, USA, 1981.

51. Collier, P.; Hoeffler, A.; Rohner, D. Beyond Greed and Grievance: Feasibility and Civil War. CSAE WPS/2006/-10. Available online: http://www.csae.ox.ac.uk/workingpapers/pdfs/2006-10text.pdf (accessed on 3 October 2015).

52. Auvinen, J. Political Instability Conflict in Less Developed Countries: Further Evidence. J. Peace Res. 1997, 34, 267-290.

53. Annett, A. Social Fractionalization, Political Instability and the Size of Government. Available online: http://www.imf.org/External/Pubs/FT/staffp/2001/03/pdf/annett.pdf pdf (accessed on 3 October 2015).

54. Duffield, M. Global Governance and the New Wars; Zed Books: London, UK, 2001.

55. Murshed, S.M. Conflict, Civil War and Underdevelopment: An Introduction. J. Peace Res. 2002, $39,387-393$. 
56. Elbadawi, E.; Sambanis, N. Why are there so many civil wars in Africa? Understanding and preventing violent conflict. J. Afr. Econ. 2000, 9, 244-269.

57. Ross, M.L. What Do We Know about Natural Resources and Civil War? J. Peace Res. 2004, 41, 337-356

58. Fearon, J.D.; Laitin, D.D. Ethnicity, Insurgency and Civil War. Am. Political Sci. Rev. 2003, 97, 75-90.

59. Bleaney, M.; Dimico, A. Ethnic Diversity and Local Conflicts. Available online: http://www.csae.ox.ac.uk/conferences/2009-EDiA/papers/461-BleaneyDimico.pdf (accessed on 3 October 2015).

(C) 2015 by the authors; licensee MDPI, Basel, Switzerland. This article is an open access article distributed under the terms and conditions of the Creative Commons Attribution license (http://creativecommons.org/licenses/by/4.0/). 